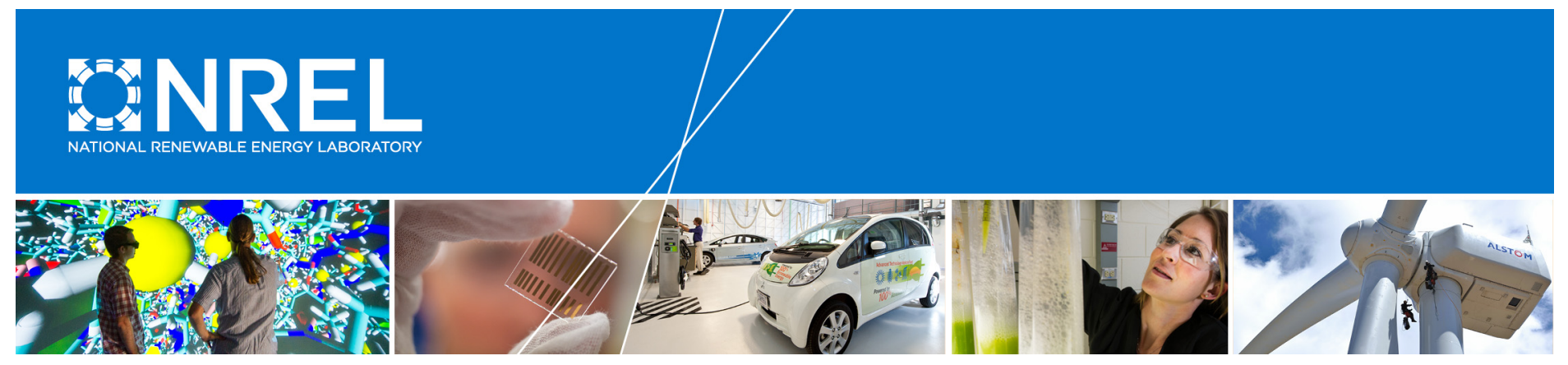

\title{
Reducing Energy Burden with Solar: Colorado's Strategy and Roadmap for States
}

Jeffrey J. Cook and Monisha Shah National Renewable Energy Laboratory

NREL is a national laboratory of the U.S. Department of Energy Office of Energy Efficiency \& Renewable Energy Operated by the Alliance for Sustainable Energy, LLC

This report is available at no cost from the National Renewable Energy Laboratory (NREL) at www.nrel.gov/publications.

Technical Report

NREL/TP-6A20-70965

March 2018 


\section{Reducing Energy Burden with Solar: Colorado's Strategy and Roadmap for States}

\author{
Jeffrey J. Cook and Monisha Shah \\ National Renewable Energy Laboratory
}

\section{Suggested Citation}

Cook, Jeffrey J. and Monisha Shah. 2018. Reducing Energy Burden with Solar: Colorado's Strategy and Roadmap for States. Golden, CO: National Renewable Energy Laboratory. NREL/ TP-6A20-70965. https://www.nrel.gov/docs/fy18osti/70965.pdf.

NREL is a national laboratory of the U.S. Department of Energy Office of Energy Efficiency \& Renewable Energy Operated by the Alliance for Sustainable Energy, LLC

This report is available at no cost from the National Renewable Energy Laboratory (NREL) at www.nrel.gov/publications.

National Renewable Energy Laboratory 15013 Denver West Parkway

Golden, CO 80401

303-275-3000 • www.nrel.gov

\section{Technical Report}

NREL/TP-6A20-70965

March 2018

Contract No. DE-AC36-08GO28308 


\title{
NOTICE
}

This report was prepared as an account of work sponsored by an agency of the United States government. Neither the United States government nor any agency thereof, nor any of their employees, makes any warranty, express or implied, or assumes any legal liability or responsibility for the accuracy, completeness, or usefulness of any information, apparatus, product, or process disclosed, or represents that its use would not infringe privately owned rights. Reference herein to any specific commercial product, process, or service by trade name, trademark, manufacturer, or otherwise does not necessarily constitute or imply its endorsement, recommendation, or favoring by the United States government or any agency thereof. The views and opinions of authors expressed herein do not necessarily state or reflect those of the United States government or any agency thereof.

This report is available at no cost from the National Renewable Energy Laboratory (NREL) at www.nrel.gov/publications.

Available electronically at SciTech Connect http:/www.osti.gov/scitech

Available for a processing fee to U.S. Department of Energy and its contractors, in paper, from:

\author{
U.S. Department of Energy \\ Office of Scientific and Technical Information \\ P.O. Box 62 \\ Oak Ridge, TN 37831-0062 \\ OSTI http://www.osti.gov \\ Phone: 865.576.8401 \\ Fax: 865.576.5728 \\ Email: reports@osti.gov
}

Available for sale to the public, in paper, from:

\author{
U.S. Department of Commerce \\ National Technical Information Service \\ 5301 Shawnee Road \\ Alexandria, VA 22312 \\ NTIS http://www.ntis.gov \\ Phone: 800.553 .6847 or 703.605 .6000 \\ Fax: 703.605.6900 \\ Email: orders@ntis.gov
}




\section{Acknowledgments}

This work was funded by the Colorado Energy Office. The authors would like to thank all the interviewees for contributing their expertise to this study. We would also like to thank the following individuals for their review of this work: Alexandra Aznar (National Renewable Energy Laboratory), Lori Bird (National Renewable Energy Laboratory), Howard Brooks (Energy Outreach Colorado), Tom Figel (GRID Alternatives), Paul Jiacoletti (Department of Energy), Joe Pereira (Colorado Energy Office), Derek Schroeder (Department of Energy), and Gillian Weaver (Colorado Energy Office). Finally, we would like to thank Mike Meshek (National Renewable Energy Laboratory) for editing and Joelynn Schroeder (National Renewable Energy Laboratory) for graphics support. 


\section{Executive Summary}

The Colorado Energy Office (CEO) recently implemented a multipronged strategy to reduce energy burden for low-income (LI) Colorado residents through the deployment of solar photovoltaics (PV). Because of these efforts, approximately $20 \mathrm{MW}$ of PV will be deployed in Colorado by the end of 2019 specifically for low-income households. Relying on interviews with 10 subject-matter experts along with archival research, this report outlines the CEO strategy, including why the agency pursued the strategy, how it was carried out, and lessons learned during its implementation.

The CEO strategy includes three major components:

- Supporting LI community solar demonstration projects

- Incorporating PV into its weatherization program

- Promoting utility investment in LI PV programs.

The CEO strategy was developed through careful analysis and with the purpose of reducing energy burden, or the proportion of household income spent on energy bills. Colorado's household energy consumption data indicated that approximately half of energy expenditures were associated with electricity and that these expenditures were expected to grow. CEO determined that given the cost decline in PV technology, LI customers could benefit from PV deployment, which can offset electricity expenses. However, low-income households have faced a variety of barriers to PV access, which has resulted in less deployment across the LI market segment. Between 2015 and 2017, CEO pursued federal, state, and ratepayer funding options to reduce those barriers and develop programs for both on-site and off-site PV to ensure broader access for LI households.

The implementation of the strategy offers several key lessons learned. First, the community solar demonstration projects revealed that LI solar projects could offer meaningful electricity bill savings for subscribers. Second, CEO's successful first-of-its-kind integration of PV into its weatherization program demonstrates how a state can leverage federal funding to support rooftop PV deployment for LI customers. Third, CEO's successful efforts to promote in-state utility investment in LI PV programs shows how this partnership can significantly expand market impact.

Though CEO's strategy is unique and tailored to the needs of Colorado, other states might learn from CEO's experiences when designing their own low-income programs. The report concludes with six primary steps a state might take when designing a comprehensive low-income solar strategy.

Step 1: Analyze Energy Burden and PV Potential: The first step a state might take is evaluating LI energy burden by housing and fuel type, and then assessing PV technical and market potential for LI households.

Step 2: Consider Financing Options: After determining PV is an effective measure to address LI objectives, policymakers may wish to evaluate all the potential funding options that could be used to support LI PV deployment. 
Step 3: Develop Program Design: If PV looks attractive for reducing LI energy burden and financing options are available, state policymakers may wish to consider program design options.

Step 4: Seek Approval: When designing a program, agency personnel will have to carry that program through the relevant approval processes.

Step 5: Implement and Learn from Pilots: Initial program design might focus on the launch of pilot projects that will allow a state to learn from its efforts and then inform broader program design.

Step 6: Assess Impact and Next Steps: Once pilots or programs are fully implemented, a state might consider evaluating the program's performance in achieving its energy burden and deployment objectives to inform future program design. 


\section{Table of Contents}

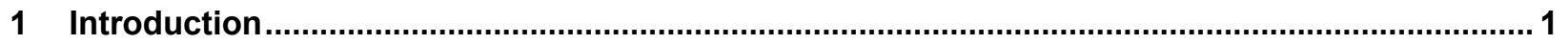

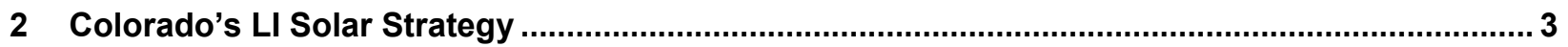

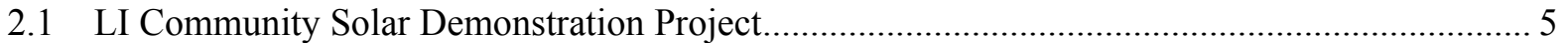

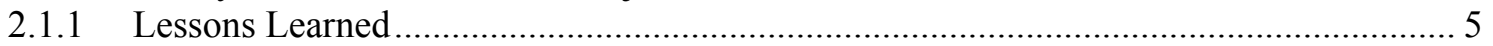

2.2 Rooftop PV via LIHEAP/WAP Demonstration Projects ....................................................... 7

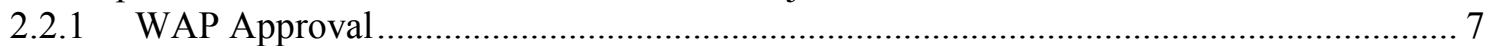

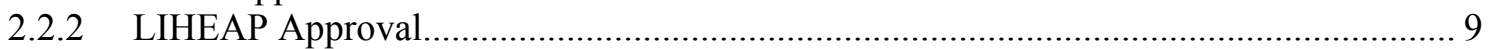

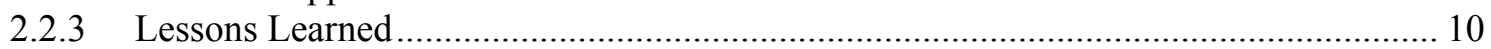

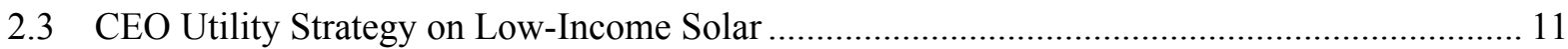

2.3.1 Low-Income Rooftop Solar Program ........................................................................ 12

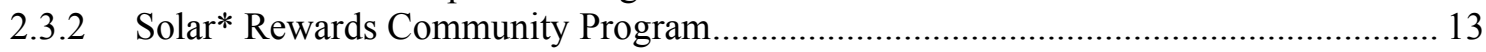

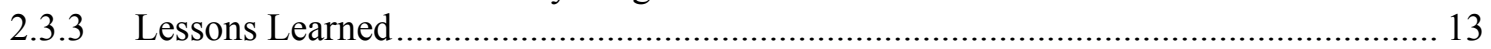

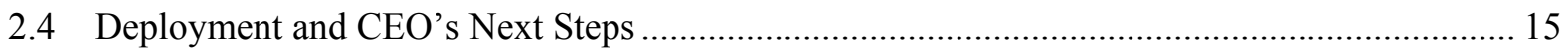

3 Roadmap for States Pursuing LI PV Programs ........................................................................ 16

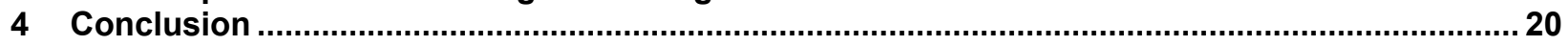

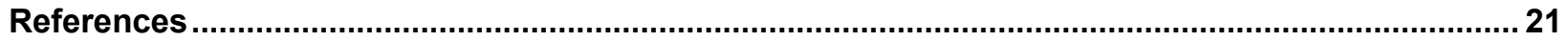




\section{List of Figures}

Figure 1. Percentage of installations by income range for three state programs .................................... 1

Figure 2. Historical Colorado residential energy prices, 2001-2015 .................................................. 4

Figure 3. Typical annual unit weatherization savings for PV and non-PV projects ................................. 4

Figure 4. Comparison of average savings associated with certain weatherization measures used in the

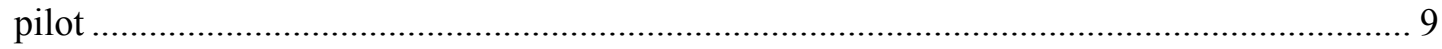

Figure 5. Roadmap for developing a comprehensive LI PV strategy .................................................. 16

\section{List of Tables}

Table 1. Typical Energy Burden for Certain Households based on Income and \$1,500 Annual Energy

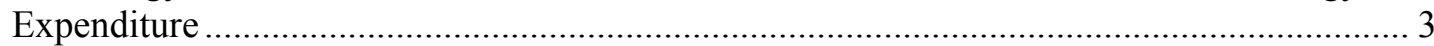




\section{Introduction}

Low-income (LI) residents suffer from a higher energy burden-or ratio of energy expenditures to overall household income - than higher-income households. ${ }^{1}$ For example, Drehobl and Ross (2016) showed that the median energy burden for LI households across 48 U.S. cities was 7.2\% as compared to an energy burden of $3.5 \%$ for the median household across all cities. In some cases, energy burden can be significantly higher for certain LI residents exceeding 14\% of total family income. ${ }^{2}$ This burden can force LI residents to decide whether to pay energy bills or for other necessities, such as medicine or food (Drehobl and Ross 2016).

One way to reduce this energy burden is to deploy on-site or off-site solar photovoltaic (PV) systems on behalf of LI households. From 2010 to 2016, residential PV capacity in the United States increased from 0.25 gigawatts (GW) to 2.6 GW (GTM and SEIA 2016). Despite this strong growth, in at least some markets, PV benefits have primarily been confined to middle and upper income families (Figure 1; Barbose et al. 2017). For example, in California, the largest residential PV market, about 5\% of PV installations are on homes with annual incomes of less than \$40,000 (Ronen, Hirsh Bar Gai, and Crampton 2016). Moreover, PV penetration levels for these California residents has remained flat, despite significant growth in PV deployment overall. If this trend holds true in other states, PV may disproportionately benefit higher-income families nationally.

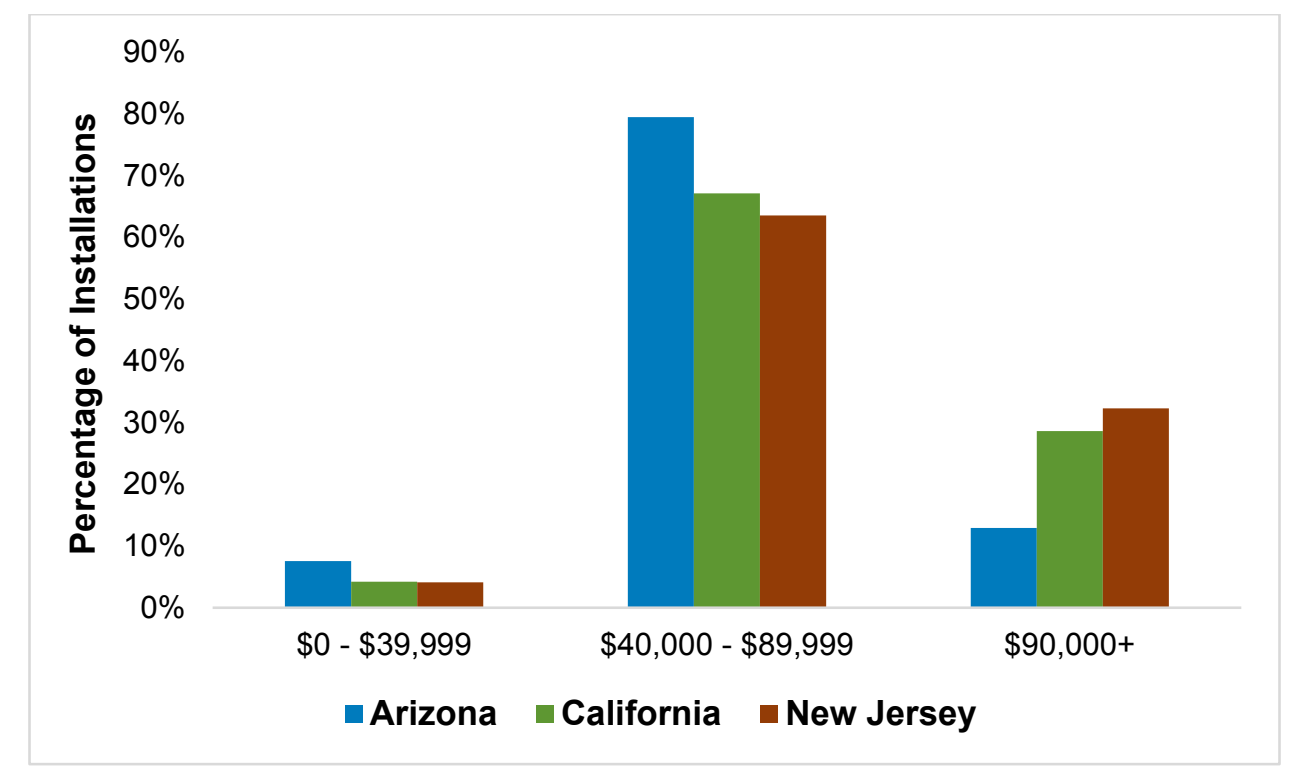

Figure 1. Percentage of installations by income range for three state programs

Recreated from Hernandez 2013

\footnotetext{
${ }^{1}$ Federal, state, and local actors define low-income residents differently, depending on programmatic goals and objectives. The Colorado Energy Office's programs target residents with incomes within $200 \%$ of the federal poverty level (CEO 2018).

${ }^{2}$ For state-by-state analysis of energy burden, see "Current Year Affordability [sic] Gap Data," Home Energy Affordability Gap website, http://www.homeenergyaffordabilitygap.com/03a affordabilityData.html.
} 
A range of issues, including homeownership status, housing assistance, and financing makes it more challenging for LI customers to benefit from both on-site and off-site PV (Cook and Bird 2018). At the same time, LI residents could significantly benefit from low-cost PV. The State of Colorado originally recognized this opportunity with the passage of the Community Solar Garden Act (House Bill 10-1342), which required community solar project developers to subscribe at least 5\% low-income customers in their Colorado projects. ${ }^{3}$ The Colorado Energy Office (CEO) has since expanded LI solar programs in the state through a three-pronged approach to maximize energy burden reductions by:

- Supporting $100 \%$ LI community solar demonstration projects

- Incorporating PV into its weatherization program

- Promoting utility investment in LI PV programs.

This report, which is based on both in-depth interviews with 10 subject-matter experts and relevant literature, outlines CEO's strategy, related programs, and lessons learned with respect to low-income PV. Our intent is to demonstrate how other states might replicate CEO's successes and learn from design and implementation challenges with integrating PV into low-income energy programs. The next section (Section 2) outlines CEO's general strategy and the key lessons learned for each component of the strategy. Section 3 provides a roadmap that other states might use to design their own low-income solar strategy based on lessons learned from the Colorado example. Section 4 offers a conclusion.

\footnotetext{
3 To review the law, see http://www.leg.state.co.us/clics/clics2010a/csl.nsf/fsbillcont/490C49EE6BEA3295872576A80026BC4B?Open\&file $=1342$ 01.pdf.
} 


\section{Colorado's LI Solar Strategy}

The mission of CEO is to deliver cost-effective energy services and advance innovative energy solutions to benefit all Coloradoans. CEO focuses its LI efforts within its Low-Income and Residential Energy Services Division (CEO 2018). The division's LI efforts are designed to address home energy burden for LI residents in all 64 Colorado counties, largely through no-cost weatherization retrofits. To help structure its offerings to LI customers, CEO has four classifications of energy burden outlined in Table 1: energy impoverished, energy burdened, energy stressed, and not burdened. The lowest income households face the highest energy burden, while those households with incomes exceeding $\$ 37,500$ are on average less burdened (Pereira 2016b).

\section{Table 1. Typical Energy Burden for Certain Households based on Income and \$1,500 Annual Energy Expenditure}

\begin{tabular}{c|lc}
\hline Annual Household Income & Classification Level & Percentage of Income Spent on Energy \\
\hline$<\$ 15,000$ & energy impoverished & $>10 \%$ \\
$\$ 15,000-\$ 21,499$ & energy burdened & $7 \%-10 \%$ \\
$\$ 21,500-\$ 37,500$ & energy stressed & $4 \%-7 \%$ \\
$>\$ 37,500$ & not burdened & $<4 \%$ \\
\hline
\end{tabular}

Source: Pereira 2016b

Approximately $11 \%$ of Colorado residents are energy impoverished (CEO 2015), and they pay on average $10 \%-15 \%$ of their income on energy (Pereira 2016b). CEO's weatherization programs are targeted at residents that are most likely impoverished or at households with annual incomes at $200 \%$ or less of the federal poverty level (CEO 2018). For a household of four in 2017, this corresponds with an annual income less than $\$ 49,200$ (ASPE n.d.). To carry out its programs, CEO relies on federal, state, and utility funding to provide no-cost weatherization services for qualifying LI residents. CEO then contracts with weatherization service providers, also termed subgrantees, that implement the weatherization measures. CEO currently oversees the performance of six regional and one statewide subgrantee to carry out its program.

To maximize LI customer savings, CEO tracks two key factors that drive energy burden: home heating and electricity usage from plug loads. In Colorado, space and water heating accounts for about $73 \%$ of overall energy usage, while plug loads represent about $27 \%$ of consumption (EIA 2009). For space heating, $71 \%$ of households in Colorado use natural gas and 21\% use electricity. ${ }^{4}$

Though space and water heating accounts for about $75 \%$ of energy usage in Colorado, energy expenditures are more evenly split between electricity and natural gas (EIA 2009). In addition, electricity costs have been steadily increasing in Colorado, while natural gas costs have remained flat for the residential sector (See Figure 2). If this trend continues, electricity costs will have an increasingly disproportionate effect on energy burden for Colorado's LI residents.

\footnotetext{
${ }^{4}$ The remaining $8 \%$ of residents use propane, some other fuel source, or no source for home heating (EIA 2009).
} 


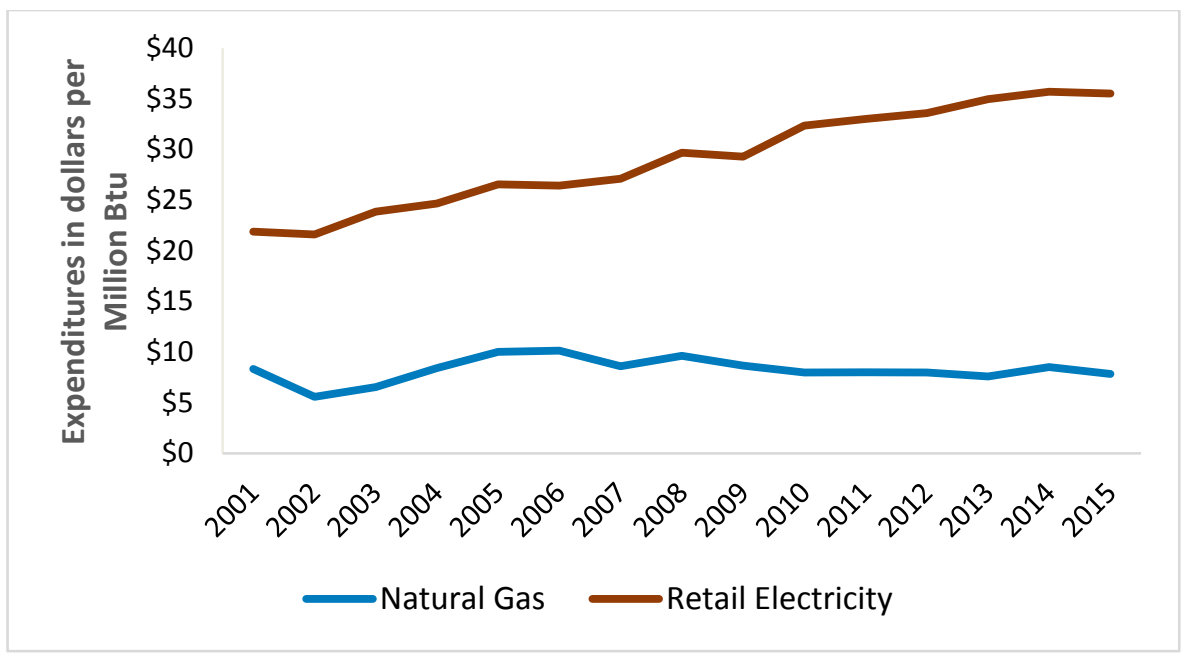

Figure 2. Historical Colorado residential energy prices, 2001-2015

Adapted from EIA 2017a

Historically, CEO has used several energy efficiency measures to reduce energy use, including installation of attic, duct, pipe, and wall insulation, along with replacement of refrigerators and lightbulbs (Pereira 2016a). CEO finds that regardless of the energy efficiency measures used to weatherize a home, incorporating PV as a measure to reduce electricity costs can increase LI customer benefit by $\$ 400$ or more annually as a result of high solar irradiance and a strong PV market in the state (See Figure 3). ${ }^{5}$

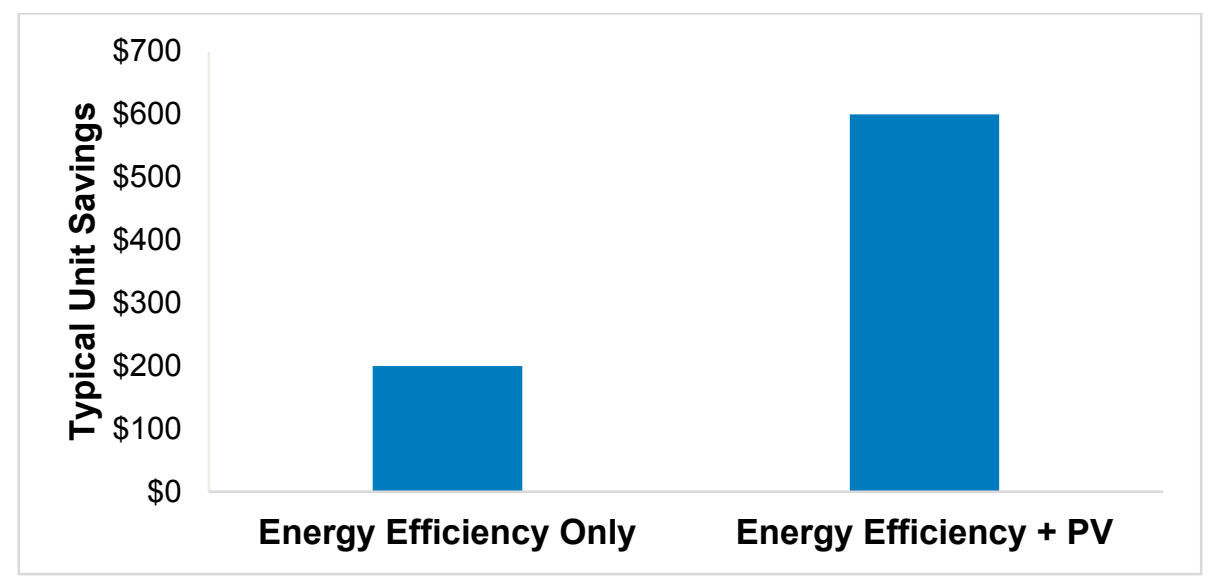

Figure 3. Typical annual unit weatherization savings for PV and non-PV projects Adapted from Pereira 2016a

Given these findings, CEO began looking for ways to more broadly deploy PV for LI customers. This included pursuing both on-site and off-site PV options, as residents may be unable to procure or host on-site PV (Feldman et al. 2015). Another benefit of this approach, from CEO's perspective, is that it offers LI customers more PV procurement options.

\footnotetext{
${ }^{5}$ Interviewees from CEO noted that program adjustments improved customer cost savings from energy efficiency measures to $\$ 300$, while PV still offers an additional $\$ 400$ savings.
} 
Ultimately, CEO adopted a multipronged strategy that includes community solar demonstration projects directed at LI subscribers, incorporation of onsite PV into its weatherization program, and promotion of utility investment in LI PV programs. In the remainder of this section, we discuss the CEO approach and lessons learned for each aspect of their strategy.

\subsection{Community Solar Demonstration Project}

The first program CEO implemented to reduce the energy burden of LI households was a community solar demonstration project with only LI subscribers; it was launched in 2015 (Dobos et al. 2017). This program had two key objectives: (1) help reduce energy burden for at least 300 LI households and (2) better understand how to make community solar programs with all LI participants mutually beneficial for utilities and participants. If successful, it would offer a roadmap for how community solar projects could be designed to serve the underrepresented low-income market.

To achieve this goal, CEO awarded GRID Alternatives, a solar installer and program administrator that specializes in the LI solar market, a \$1.2 million grant that required a 2:1 funding match from identified utility partners. GRID Alternatives partnered with eight utilities including Empire Electric Association, Delta-Montrose Electric Association, Fort Collins Electric Utility, Grand Valley Power, Holy Cross Energy, Poudre Valley Rural Electric Association, San Miguel Power Association, and Yampa Valley Electric Association. GRID Alternatives and its utility partners then pursued LI community solar projects that provided nocost subscriptions to LI households.

Eight LI community solar projects totaling approximately 1.5 MW have been constructed across the eight utilities (Dobos et al. 2017). Almost 400 LI households currently receive an electric utility bill credit for their subscription in these projects; the credit provides annual bill savings ranging from $15 \%$ to $50 \%$. The variation in savings is largely a function of subscription size and the structure of electricity rates at each cooperative (e.g., level of fixed charges versus volumetric charges). Some utilities offer individual households the opportunity to offset more of their electricity demand through larger subscriptions, which results in more bill savings. Meanwhile, because bill credits are on a per kilowatt-hour basis, utilities with higher fixed charges can influence bill savings regardless of a customer's subscription size. From the utilities' perspective, the projects demonstrated the feasibility of developing LI community solar projects that offer immediate bill savings for participating customers. In fact, Dobos et al. (2017) suggest it would be possible to recoup utility costs for a LI community solar project and to provide LI customers a $10 \%$ energy bill savings, absent government or other third-party investment. At the same time, utilities had the opportunity to understand a potentially new market segment, LI households, and opportunities for expanding solar access broadly through community solar. ${ }^{6}$

\subsubsection{Lessons Learned}

Dobos et al. (2017) provide a thorough discussion of the lessons learned from these community solar demonstration projects. The goal of this section is to highlight some of the key themes

\footnotetext{
${ }^{6}$ The utilities also retained the renewable energy credits associated with the projects or sold them to their wholesale electricity supplier (Dobos et al. 2017).
} 
as they relate to reducing energy burden for individual LI customers and fostering a scalable LI community solar market.

For individual LI customers, their bill credit and the structure of their electricity rate were key factors driving the reduction in their energy burden. A utility that offered a larger bill credit and subscription size saw more savings for participants. Taking this approach allows individual LI customers to maximize individual savings. On the other hand, limiting subscription sizes can ensure more LI customers can participate and benefit from PV. As a result, interviewees from CEO commented they had capped individual subscriber electric bill savings to a maximum of $50 \%$, to increase the number of LI households that participate while encouraging customers to conserve energy for additional savings. ${ }^{7}$ Determining the right balance between subsidizing individual bill savings and expanding overall LI participation represents an important ongoing question for program administrators. Additionally, rate design also influenced LI household savings. Utilities having a higher proportion of fixed charges in electric rates versus volumetric charges affected the level of household savings. Assessing how fixed charges may influence savings is another important consideration when structuring community solar programs. ${ }^{8}$

These eight projects also offer some important lessons with respect to building a market for LI community solar. For example, interviewees from CEO said one reason the state focused on cooperative and municipal utilities was that they could make community solar procurement decisions relatively quickly, given fewer regulatory approval requirements. However, some cooperatives can face significant challenges when they build their own generation sources while under contract with a wholesale power provider. In some cases, utilities may be limited to a certain amount of utility-owned generation (e.g., 5\% of load) and may not be able to build more projects after that threshold is met (Dobos et al. 2017). This can limit their ability to procure electricity generation, even with state subsidies. Thus, states may wish to consider these challenges, when they seek utility partners for LI projects.

Finally, existing financial incentives could attract more investment in LI community solar projects. For example, only one of the projects within this pilot program was able to monetize applicable tax credits that could reduce the overall cost of the project, such as the federal investment tax credit (ITC). ${ }^{9}$ In general, the cooperatives in this program were not directly eligible for the ITC. However, the Poudre Valley Rural Electric Association signed a 12-year leaseback financing structure with CoBank, a trusted cooperative partner that could monetize the credit (Dobos et al. 2017). Pursuing tax partners, as was done in the latter case, reduces overall project costs making it easier to provide LI customers a sizable bill savings or reduce utility and state investment.

\footnotetext{
${ }^{7} \mathrm{CEO}$ also stressed the importance of pairing community solar with energy efficiency measures at the home. In line with this focus, subscribers were selected from a list of previously weatherized homes or were required to apply for weatherization services. As a result, the cumulative savings of these combined measures are likely higher than the electricity bill savings ranges presented here.

${ }^{8}$ For more information on how rate design can influence end-user energy consumption and policy objectives see Baatz 2017.

${ }^{9}$ For more information on the ITC, see https://energy.gov/savings/business-energy-investment-tax-credit-itc.
} 


\subsection{Rooftop PV via LIHEAP/WAP Demonstration Projects}

While implementing the community solar demonstration projects, CEO was also pursuing additional pathways for LI residents to benefit from on-site PV. CEO receives federal weatherization and energy assistance funds from both the U.S. Department of Energy (DOE) Weatherization Assistance Program (WAP) and the U.S. Department of Health and Human Services' (HHS) Low Income Home Energy Assistance Program (LIHEAP). State grantees for both programs can potentially use both pools of funding for PV deployment on LI households. Though funds from LIHEAP and WAP can be used for PV, they have different approval and programmatic requirements. CEO first pursued using WAP program funds for PV, and once it was granted approval, it also requested to use LIHEAP funds. In this section, we discuss the process CEO took to receive WAP approval for PV and then specifically for four WAP pilot projects; we then discuss CEO's efforts to receive LIHEAP approval.

\subsubsection{WAP Approval}

Since 1976, Colorado and other states have received WAP funds to provide no-cost energy efficiency retrofits to eligible low-income families. Overall funding for the WAP program is determined by annual appropriations from Congress. DOE then distributes this funding to states via an annual formula-based process. ${ }^{10}$ In Fiscal Year 2017, DOE granted Colorado approximately $\$ 5.5$ million for its WAP efforts (DOE 2017a). To access such WAP funding, states must apply to use funds by submitting an annual weatherization plan that demonstrates the program complies with DOE WAP regulations. The technical portion of the plan is reviewed by the state's DOE project officer, and the plan must then be approved by the DOE contract officer before funding is distributed. If approved, states can use the funds for individual weatherization projects that incorporate approved weatherization measures.

Until the passage of the Energy Policy Act of 2005, PV was not an eligible weatherization measure. Though the law allowed the use of WAP funds for PV, it capped expenditures at an average of $\$ 3,000$ per dwelling unit. ${ }^{11}$ This expenditure threshold is adjusted annually based on a cost of living adjustment, and in 2017, the limit was set at \$3,598 (DOE 2017b).

Before WAP funds can be used for PV, DOE must approve a state's plan. To receive approval, a state needs to demonstrate the measure is likely to be cost effective (DOE 2016). If DOE signs off on the inclusion of PV in a state's plan, the state must then demonstrate that individual projects that would incorporate PV are also cost effective. This approval requires demonstrating a savings-to-investment ratio (SIR) greater than 1.0 for a new technology measure such as PV (DOE 2012).

As CEO had limited guidance for how it could demonstrate PV's cost effectiveness, CEO staff worked with their DOE project officer to identify an approvable method. CEO used cost and performance data on an existing solar system available in the market and conducted SIR analyses to demonstrate that PV was likely to be cost-effective for weatherization projects in the state.

\footnotetext{
${ }^{10}$ For more information on the WAP allocation formula, see "Weatherization Assistance Program Allocation Formula, DOE, https://energy.gov/eere/wipo/weatherization-assistance-program-allocation-formula.

${ }^{11}$ See the language of the law on the at the U.S. Government Printing Office website at https://www.gpo.gov/fdsys/pkg/PLAW-109pub158/html/PLAW-109publ58.htm.
} 
CEO then incorporated these SIR analyses into their formal application, which they submitted in May 2015. Colorado also submitted a request for an environmental review to DOE, which was approved to allow PV roof installations that did not exceed five kilowatts $(\mathrm{kW})$ of capacity. This review is required by the National Environmental Policy Act (NEPA) of 1969, which stipulates a federal agency such as DOE must conduct an environmental assessment before federal funds can be used for a specific project. In this case, DOE concluded Colorado's program was consistent with the NEPA categorical exclusion B5.16. Solar PV systems that allow DOE funding for the installation of rooftop PV in certain situations (Pereira 2016c). DOE granted CEO final approval to install residential PV in weatherization projects October 6, 2015 (Pereira 2016c).

After approval of its state plan, CEO pursued a pilot PV project in partnership with one of its six weatherization subgrantees, Energy Resource Center. Colorado Springs Utilities and El Paso Green Energy, a PV installer, were also important partners (Higgins, Lehermeier, and Brooks 2016). The pilot project was composed of four rooftop PV systems ranging from $1.7 \mathrm{~kW}$ to $2.2 \mathrm{~kW}$ that would be installed at homes that the Energy Resource Center identified for weatherization. El Paso Green Energy then offered discounted PV installations at \$2.35 per watt, which is significantly lower than the average residential PV system cost nationwide (Fu et al. 2017).

To pay for the installations, CEO leveraged DOE funds to cover $\$ 1.35$ per watt, while the remaining \$1 per watt was paid through an upfront incentive from Colorado Springs Utilities (Stewart et al. 2017). ${ }^{12}$ In August 2016, Energy Resource Center worked with El Paso Green Energy to install the first 2-kW rooftop PV array as a part of the pilot program, and the fourth project was installed in March 2017. These PV arrays were installed in a similar manner to all other WAP-approved measures in accordance with the state's plan and WAP requirements. According to CEO data, the PV projects accounted for on average $41 \%$ of the savings across the projects, followed by appliance and lighting measures, and finally other energy efficiency measures as displayed in Figure 4. Overall, this $41 \%$ savings is associated with about $\$ 400$ of annual energy savings per household.

${ }^{12}$ Colorado Springs Utilities retained the renewable energy credits from each project. 


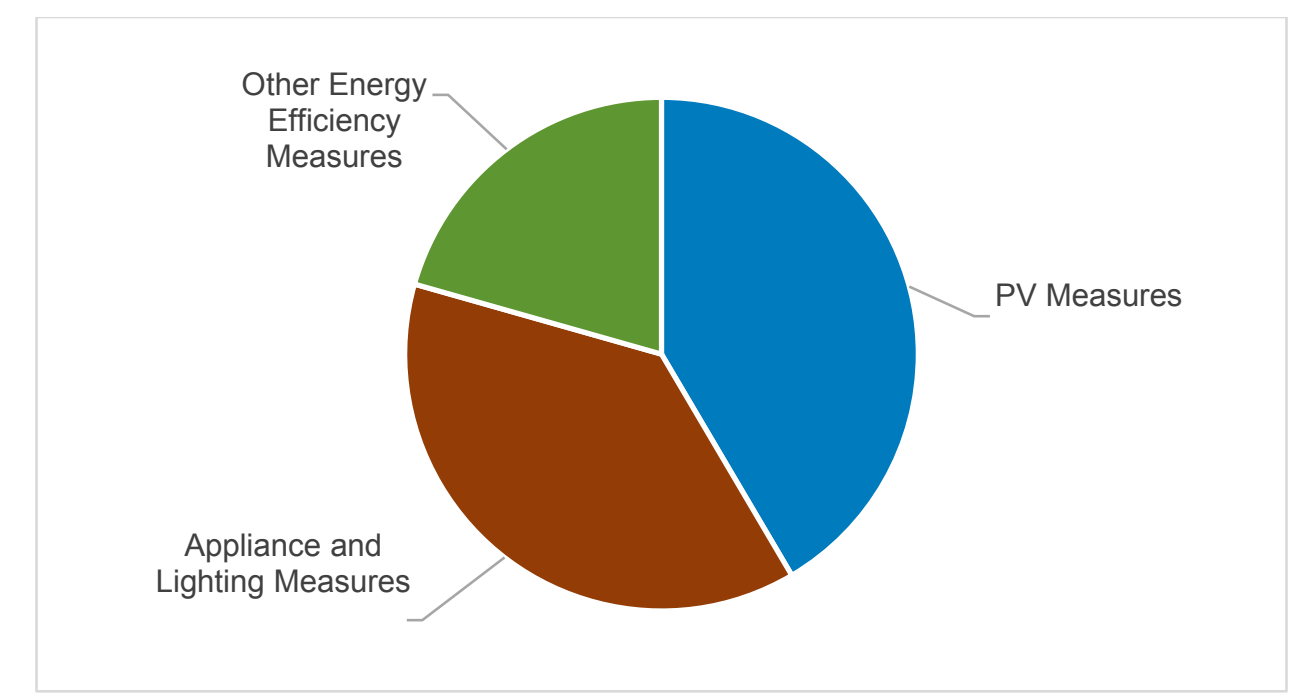

Figure 4. Comparison of average savings associated with certain weatherization measures used in the pilot

Data provided by CEO.

During the implementation of the pilot project, CEO submitted its 2017 Annual Plan, which included rooftop PV. In March 2017, DOE finalized its NEPA review, which concluded the program was in line with the categorical exclusion B5.16 for rooftop PV (DOE 2017c). This decision allowed CEO to continue using weatherization funds for PV installations, pending DOE approval for specific projects. CEO has since installed more rooftop PV systems that are associated with a partnership program between Xcel Energy ${ }^{13}$ and CEO (see Section 2.3).

\subsubsection{LIHEAP Approval}

CEO followed a different path for pursuing LIHEAP funding for PV projects, in part because the agency does not administer this program for the state. Rather, LIHEAP funds are distributed from HHS to the Division of Food and Energy Assistance within the Colorado Office of Economic Security. In Fiscal Year 2017, the Division of Food and Energy Assistance received \$51 million in LIHEAP funds for energy bill assistance (HHS 2017). The release of these funds was contingent on the approval of the state's annual LIHEAP plan. In that plan, the division can devote up to $15 \%$ of their LIHEAP funds to weatherization projects, or up to $25 \%$ with an approved waiver from HHS (HHS 2016). In Fiscal Year 2016, 47 states and the District of Columbia incorporated weatherization into their LIHEAP plans, with a range of $2 \%-15 \%$ of LIHEAP funds dedicated to weatherization (HHS 2016). Colorado was one of 28 states that opted to use $15 \%$ of its LIHEAP funds for weatherization, and no state received a waiver to allocate more than $15 \%$ to weatherization (HHS 2016).

To approve a LIHEAP plan with a weatherization component, a state must address three important issues in its plan. The state needs to clarify what agency will oversee weatherization, the regulations that agency will follow, as well as the specific weatherization measures the agency plans to use. States are granted the authority to determine which agency will implement weatherization, because states commonly have one department that manages weatherization and another that oversees energy bill assistance programs.

\footnotetext{
${ }^{13}$ Xcel Energy is also referred to as Public Service Company of Colorado.
} 
Thus, states are allowed flexibility to pass LIHEAP funds through to other departments that implement weatherization. In line with this flexibility, the implementing agency can apply DOE's WAP regulations, LIHEAP's regulations, or some combination of the two. The regulations that a state applies can influence the type of measures that can be selected and the process for incorporating PV. Ultimately, LIHEAP regulations related to weatherization are more flexible than WAP because the law does not call out specific approved weatherization measures. Instead, any low-cost, cost-effective weatherization measure that does not constitute construction can be eligible for approval. Thus, PV can be incorporated as an "other weatherization" measure in a state's plan, with fewer requirements than is the case in DOE's WAP program, assuming LIHEAP rules are used (HHS 2016).

Though Colorado LIHEAP funds have been transferred to CEO for weatherization purposes in the past, PV was first included as a weatherization measure in the state LIHEAP plan in Fiscal Year 2017 (Colorado Department of Human Services 2017). In the application, the Division of Food and Energy Security requested $15 \%$ of its LIHEAP funds be allocated to weatherization, and it designated CEO to oversee weatherization. The plan also clarifies that CEO will apply LIHEAP rules with three key exceptions. For ease of implementation, DOE's WAP regulations will be used in relation to income thresholds, multifamily housing eligibility, and administrative definitions rather than LIHEAP rules on these topics. The plan also included rooftop PV as an "other weatherization" measure that might be used when replacing a primary heating system. HHS approved the plan and interviewees noted that CEO used these fund in relation to the Xcel Energy rooftop PV program outlined in Section 2.3.

\subsubsection{Lessons Learned}

Interviewees provided a variety of lessons learned from CEO's efforts to incorporate PV into its weatherization program. Here we focus on approval processes and program implementation. Some of the approval-related challenges CEO faced stemmed from the first-of-a-kind nature of Colorado's plan. This made the development of the initial application to incorporate PV time and resource intensive, especially the SIR analysis for a hypothetical project. Since CEO received approval, NREL has developed an SIR tool to help states reduce time and resource needs associated with assessing PV cost-effectiveness (EERE 2016). In addition, CEO's approved plan can serve as a starting point for other states as can subsequently published guidance from DOE in the form of WAP Memo 024 (DOE 2017b). Nevertheless, each state's plan and justification are likely to differ and to require some time and resources to produce. The DOE project officer must also approve the technical portion of the plan. Engaging with the project officer early in the process and providing the project officer with strong solar analysis with citable data and relevant background information may allow a more streamlined approval process.

The implementation of the CEO program has also provided some important insights. First, CEO has recognized that $10 \%-20 \%$ of weatherization-eligible homes can support PV installations (Stewart et al. 2017) because of electrical and roof conditions. In other cases, customers may not have access to solar because of shading or building orientation. Interviewees said this is one reason CEO has focused on deploying both on-site and off-site PV to support LI residents where appropriate.

Second, though it was possible for PV projects to reach an SIR greater than 1.0 using only the DOE WAP funding, pursuing other willing financing partners (e.g., utilities) would result in 
greater benefits to LI households. As a result, CEO sought outside funding to help increase system size and reduce energy burden. In the pilot projects, this resulted in partnerships with the $\mathrm{PV}$ installer and the utility. CEO has since pursued Xcel Energy funding, as discussed in Section 2.3. A funding option that CEO did not use was the ITC. Though CEO and Energy Resource Center are non-taxable entities, they could have pursued a financing partner to benefit from the ITC. However, the small project sizes may influence the tax benefit savings versus administrative costs, making these systems less attractive to potential partners.

Third, interviewees from CEO suggested the implementation of this new measure, like implementing other new initiatives, came with process challenges and delays related to establishing new state contracts and programmatic procedures. Interviewees went on to suggest that building flexibility into programs, particularly around deployment timelines, might help navigate these challenges.

\subsection{CEO Utility Strategy on Low-Income Solar}

While CEO was implementing its community solar and rooftop PV programs, Xcel Energy, Colorado's largest investor-owned utility, submitted three applications to the Colorado Public Utilities Commission (CO PUC) addressing rates, corporate renewable energy procurement, and renewable energy standard compliance. The results of these proceedings would have significant impacts on LI household electricity costs and the availability of renewable energy programs from 2017 to 2019. As a result, CEO intervened on behalf of LI customers and all ratepayers.

Xcel Energy, operating as Colorado Public Service Company, covers 53\% of all retail sales in Colorado, and their programs have a significant impact on electricity rates and procurement options for customers (EIA 2017b). For example, all Xcel Energy ratepayers contribute to certain utility accounts, including the Renewable Energy Standard Adjustment (RESA), a monthly $2 \%$ electricity bill adder associated with the state's renewable portfolio standard. Through December 2017, Xcel Energy had collected over \$523 million via RESA (Xcel Energy 2018) and is required to use these funds for a variety of programs, including the Solar* Rewards for Residences program. In this program, Xcel Energy offers a $\$ 0.02$ per kilowatt-hour incentive to residential customers who install rooftop PV. ${ }^{14}$ The CO PUC structures RESA expenditures and other programs through the regulatory proceeding process. CEO frequently intervenes in these proceedings to advocate on behalf of its mission to support innovative and cost-effective energy solutions for Colorado residents.

The CO PUC originally opened three dockets to consider Xcel Energy's applications. Given the interconnected nature of the three filings and controversy surrounding previous rate and solar compensation proceedings, Xcel Energy reached out to some stakeholders in Colorado to discuss the documents and a path forward (SEPA 2017). CEO was one of the stakeholders that was initially consulted by Xcel Energy along with solar installers, municipal governments, and certain ratepayer organizations. From these initial discussions, the idea of conducting a global settlement that addressed all three proceedings was identified. Ultimately, this resulted in negotiations among 26 stakeholders to determine a path forward, which began in May 2016.

\footnotetext{
${ }^{14}$ For more information on this program, see "Xcel Energy: Solar* Rewards Program," DSIRE, http://programs.dsireusa.org/system/program/detail/1255.
} 
In August 2016, Xcel Energy submitted a global settlement, approved by the 26 stakeholders including CEO. ${ }^{15}$ In September 2016, the CO PUC held hearings on the settlement, in which stakeholders debated a variety of topics, including the inclusion of LI PV programs (CO PUC 2016a).

One of CEO's core goals in this proceeding was to increase renewable energy options for LI customers (Pereira 2016b). This goal was driven by the expectation that higher-income customers have disproportionately benefited from available renewable incentive programs, even though LI customers have also paid into some utility funds, including RESA. By one estimate, LI customers have contributed approximately \$45-\$71 million in RESA payments without receiving a direct benefit (Figel 2016). GRID Alternatives argued LI ratepayers were likely unable to benefit from RESA-related incentives because of other barriers to solar investments, such as a high upfront cost. From this basis, CEO and other stakeholders argued this was an equity issue and thus the use of RESA funds was justified to broaden access to PV for low-income Colorado residents (Figel 2016; Pereira 2016b). Ultimately, the design of LI programs became a critical component of the negotiations and the final settlement.

The CO PUC approved the settlement on November 9, 2016, and it included two key programs that relate to LI customers: the low-income rooftop solar and the Solar* Rewards Community programs (CO PUC 2016b). We discuss each program below.

\subsubsection{Low-Income Rooftop Solar Program}

The low-income rooftop solar program was designed as a partnership of CEO and Xcel Energy that builds on the WAP pilot program (Xcel Energy 2016). As was the case with the pilot projects, CEO oversees the installation of PV systems along with other weatherization measures and Xcel Energy subsidizes the cost of PV installations. In this case, Xcel Energy commits an upfront \$2.00 per watt incentive from the RESA fund for PV systems as well as a $\$ 0.034 / \mathrm{kWh}$ production-based incentive after interconnection. In addition, individual customers receive the net metering credit associated with the system. In exchange, the utility will retain all renewable energy credits from the systems for compliance with the state's renewable portfolio standard. The program will cover no more than 300 homes from 2017 to 2019 and will be completed in phases, with 75 homes being completed in 2017, 100 in 2018, and 125 in 2019. Each system will have a maximum size of $3.5 \mathrm{~kW}$, and each project will incorporate all cost-effective weatherization measures. CEO will determine which homes are eligible for the program and will publish an annual summary of the program's implementation that will be included in Xcel Energy's renewable portfolio standard compliance report.

Even though the first year of implementation for the program was 2017, installations did not begin until June 2017. According to interviewees, 70 weatherization projects that incorporate rooftop PV were pending, queued, under construction, or interconnected. According to data provided by CEO, the average system size across these projects is $3 \mathrm{~kW}$. For projects that have been constructed, the average system cost is about $\$ 3.20$ /watt and each system is expected to provide about $\$ 400$ in energy cost savings annually.

\footnotetext{
${ }^{15}$ For a detailed discussion of the settlement process, see SEPA (2017).
} 


\subsubsection{Solar* Rewards Community Program}

The Solar* Rewards Community program provides a second option for LI residents to benefit from PV through participation in community solar projects (Xcel Energy 2016). This program has three key parts. First, Xcel Energy's existing community solar program requires $5 \%$ of subscribers to individual community solar projects be LI customers. The settlement stipulates that Xcel Energy will assume this subscription obligation, by owning dedicated LI community solar projects of up to $6 \mathrm{MW}$. Second, each year, the utility will issue an annual request for proposals for $4 \mathrm{MW}$ of additional $100 \%$ LI community solar projects beyond their existing community solar requirements. The developer can request either a production-based incentive for the generation of a qualifying facility or that the incentive be paid upfront. The incentives will be generated based on the real or estimated generation of each system, and they will be paid from the RESA account. Xcel Energy will select community solar project bids based on a variety of criteria, including percentage of bill reduction, solar job training, coordination with energy efficiency programs, and subscriptions across housing types. Third, the utility will offer a lowincome standard offer that will set aside $0.5 \mathrm{MW}$ of the required community solar program capacity for small $(<100 \mathrm{~kW}) 100 \% \mathrm{LI}$ community solar projects. Qualifying facilities will receive the same upfront benefits as other $100 \%$ LI projects, and an additional $\$ 0.01 / \mathrm{kWh}$ REC adder.

In August 2017, Xcel Energy released a request for proposals for the competitive procurement of 4 MW of LI community solar (Werley 2017). In November 2017, Xcel Energy selected winning bids ${ }^{16}$ and the first set of projects are expected to come online in 2019. Interviewees noted that these bids served as the foundation for designing the 0.5 -MW set-aside for small $(<100 \mathrm{~kW})$ systems, which was launched in December 2017. These projects will be selected and approved on a first-come, first-served basis and will follow the same implementation timeline as the competitive procurement. As a result, interviewees suggested the projects may come on line in 2019. Finally, Xcel Energy is also working on implementing the 5\% subscription target. Interviewees suggested the utility is currently considering how to design this program and is establishing ownership structures. According to interviewees, the first project related to this target may not be constructed until late 2018 .

\subsubsection{Lessons Learned}

CEO's involvement in Xcel Energy's proceeding and the implementation of the resulting programs resulted in a variety of lessons learned regarding the settlement process, the LI rooftop program, and the community solar program. Here, we discuss each in turn.

First, CEO and other stakeholders' perspectives on the outcome and design of the settlement agreement are outlined in detail in SEPA (2017). Some of the key suggestions to improve the process by which the settlement was generated are as follows:

- The negotiations could have been better organized to allow more feedback from participants.

- Requiring stakeholders to clarify, in writing, their key issues and concerns earlier in the process would have been beneficial.

\footnotetext{
${ }^{16}$ The winning bids have not been publicized.
} 
- Incorporating more diverse perspectives, particularly from underserved communities, would also improve the process.

Despite these and other issues, participants suggested the settlement agreement process could serve as a foundation for improving regulatory proceedings going forward because it was relatively successful in resolving contentious issues and it built trust among participants. Stakeholders suggested the process could be fruitfully deployed in certain contexts, though it may not be appropriate in all cases.

Outside the process to generate the settlement agreement, interviewees highlighted some key factors that helped ensure LI PV stipulations were incorporated in the settlement. Interviewees suggested the conclusion that LI residents had contributed to utility programs and likely did not receive direct benefits was important to the CO PUC in approving the rooftop and community solar programs. To address the lack of low-income customer interest in existing renewable programs, the stakeholders worked with the utilities to dedicate significant future RESA payments to benefit LI customers directly. Stakeholders, including GRID Alternatives, suggest the settlement represents a framework for equitable solar policy in Colorado (SEPA 2017).

Both the rooftop and community solar programs are in their first year of implementation, so these programs are likely to evolve. Even so, interviewees offered some perspective at this formative stage for both. Interviewees from CEO suggested that successfully navigating the state procurement process, including establishing new state contracts, has been a challenge for the rooftop program. This has made it difficult for the state, and its subgrantees, to ramp up and meet the year-one target of 75 households. Interviewees posited that as the state and subgrantees implement the program, these issues should become less challenging. In comparison, receiving approval from the state and DOE for specific PV projects will be an ongoing challenge, adding layers of complexity that may increase project timelines. At the same time, interviewees identified some opportunities for installation cost savings, including using subgrantee in-house labor for PV installations while also seeking pathways to monetize available tax credits. These savings opportunities could reduce the cost of installations and potentially increase deployment. In addition, some subgrantees have received approval to install ground-mounted PV systems to overcome roof quality issues.

Finally, Xcel Energy is just beginning to procure community solar projects, so interviewees offered lessons learned primarily related to the LI competitive procurement request for proposal process. First, developer interest was robust and far exceeded the 4-MW cap. Xcel Energy has had to determine which projects to pursue, in line with the procurement objectives outlined in the settlement. Xcel Energy is finalizing the winnings bids, and some interviewees were interested in how the utility weighted the procurement criteria when reviewing the bids. The settlement agreement did not clarify how certain criteria (e.g., bill reduction and variation in subscriber housing type) should be weighted so the utility has the flexibility to make those decisions with PUC staff approval. Going forward, some suggested it might be helpful to establish clear guidance on which criteria are most important to ensure the program achieves its objectives, including maximizing LI household benefits. Moreover, building more transparency into the bid selection process was also cited as an option to improve the process. Once Xcel Energy has fully implemented these initiatives, there may be more lessons learned for Colorado and other interested states. 


\subsection{Deployment and CEO's Next Steps}

Collectively, the aforementioned LI programs may support approximately $20 \mathrm{MW}$ of LI-related PV deployment through 2019. ${ }^{17}$ Much of this capacity expansion is associated with Xcel Energy's LI-related community solar requirements, and it is followed by the community solar demonstration projects and the CEO-Xcel Energy rooftop PV program. Ultimately, this level of deployment requires full implementation of these LI-related programs through 2019.

Interviewees offered some insights into the future of LI PV programs at CEO. First, CEO is committed to learning from implementing these programs to better serve LI customers. And, the lessons learned from these first-generation programs could then influence next-generation policies and programs. In line with a next-generation perspective, interviewees from CEO listed two LI market segments for possible future investment: multifamily (two or more housing units) and manufactured housing. ${ }^{18}$ These two housing types offer unique barriers to PV deployment, which have limited LI access to PV (Cook and Bird 2018). At the same time, both represent a significant market opportunity to broaden PV access in Colorado, as an estimated 222,000 LI households or $30 \%$ of LI residents reside in these housing types. ${ }^{19}$ Nevertheless, the pursuit of these and other LI PV initiatives are subject to CEO priorities and funding.

\footnotetext{
17 This estimate assumes the maximum LI-related deployment occurs in Xcel Energy's program and each household in the rooftop program receives the maximum $3.5 \mathrm{~kW}$ rooftop PV system.

${ }^{18}$ Manufactured housing is defined as a residential structure that is transportable in one or more parts and is built on a permanent chassis and used primarily as a residence (Cook and Bird 2018).

${ }^{19}$ This estimate is based on the EIA's 2015 Residential Energy Consumption Survey (RECS) subregional census data for the Mountain North (including Colorado, Idaho, Montana, Utah, and Wyoming) relating to housing unit type and annual household income of less than \$40,000. See "2015 RECS Survey Data," Energy Information Administration (EIA), https://www.eia.gov/consumption/residential/data/2015/\#structural.
} 


\section{Roadmap for States Pursuing LI PV Programs}

Ultimately, the CEO strategy is only one example of how states can develop a comprehensive approach to support PV deployment among LI residents. Nevertheless, CEO's efforts offer a clear roadmap for other states, particularly those considering pursing WAP or LIHEAP funding for PV. This section outlines six important steps a state might take when analyzing PV program design (see Figure 5). Though the steps are displayed sequentially, the activities may be executed in a different order as a result of differences in state laws, agency structure, and other contextual factors.

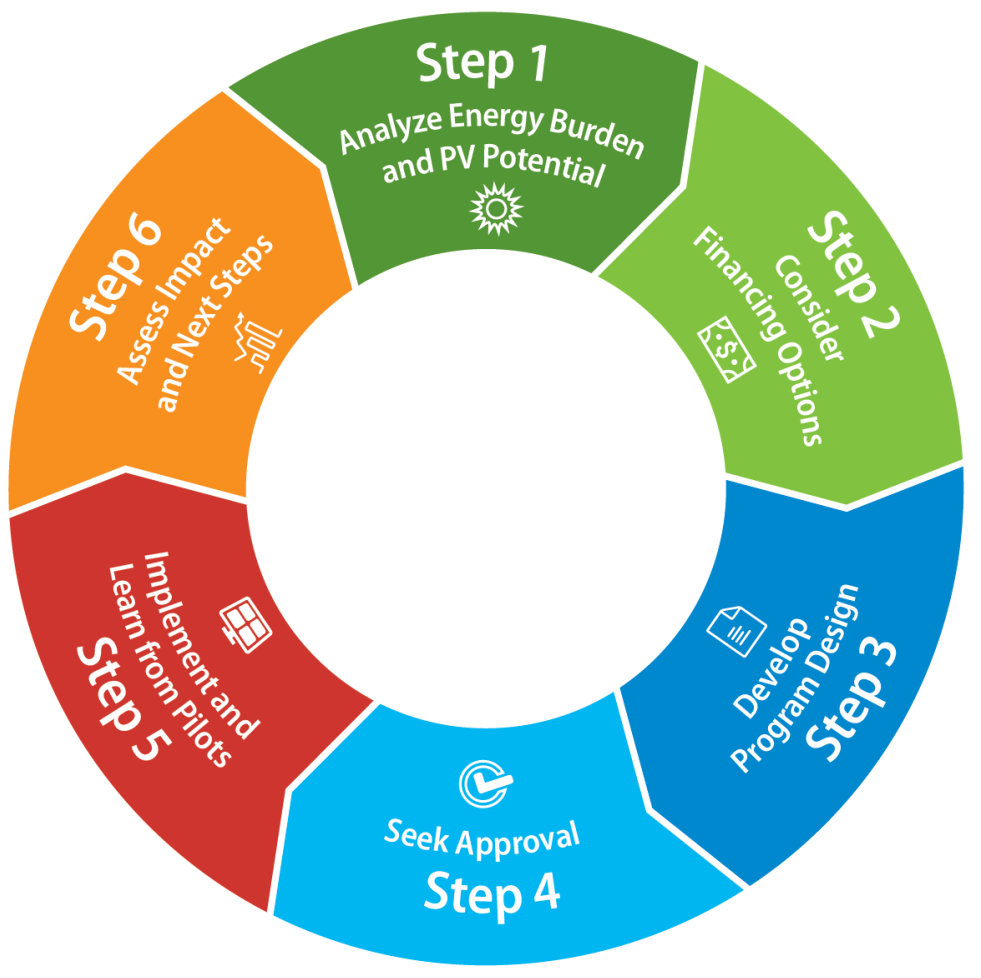

Figure 5. Roadmap for developing a comprehensive LI PV strategy

\section{Step 1: Analyze Energy Burden and PV Potential}

The first step a state might take is evaluating LI energy burden and the key factors that influence that burden, including income data and energy bill information for local LI households. A few recent methodologies and national data sets can help with this type of analysis. For example, the Clean Energy for Low Income Communities (CELICA) recently released the Low-Income Energy Affordability Data (LEAD) tool, ${ }^{20}$ which catalogues many different characteristics of low-income populations across the country, including housing type, average monthly energy expenditures, and energy burden. Variation in local low-income housing stock may also influence the approach considered by a state. In Colorado, CEO focused on deploying both on-

\footnotetext{
${ }^{20}$ This tool can be accessed at "Low-Income Energy Affordability Data (LEAD) Tool," https://catalog.data.gov/dataset/clean-energy-for-low-income-communities-accelerator-energy-data-profiles-2fffb.
} 
site and off-site PV to support LI residents with single family homes as well as renters and other homeowners who may not be able to pursue on-site solar.

For PV to play a meaningful role in reducing energy burden, electricity bills ought to comprise a significant portion of LI household energy bills. In Colorado households, even though on average, electricity consumption is much lower than natural gas consumption, the electricity rates are much higher and therefore energy bills were often split between electricity and natural gas, which presented a reasonable basis for PV as a measure for addressing energy burden.

Next, a state may want to assess PV technical and market potential for LI households. ${ }^{21}$ To assess solar irradiance and system performance, states might leverage existing tools such as PV Watts or the System Advisor Model. ${ }^{22}$ An assessment of the local PV market will also be a factor in determining the appropriateness of PV as a measure to address energy burden. The number of developers, their level of experience, the cost of installation, available financing structures, and state incentives can also affect the viability of LI solar projects. These technical and market factors will inform both the cost-effectiveness and suitability of PV as an option for reducing energy burden.

\section{Step 2: Considering Financing Options}

After determining that PV is an effective measure to address LI objectives in a given state, policymakers may wish to evaluate all the potential funding options that could be used to support LI PV deployment (Cook and Bird 2018; Paulos 2017). These can include federal dollars such as WAP and LIHEAP funds, as well as state taxpayer-funded programs or incentives. In addition, a state may wish to pursue partnerships with local utilities to leverage existing funding streams (e.g., low-income programs, renewable energy programs, and other related efforts) to deploy LI PV as occurred in Colorado, especially to encourage more equitable incentive distribution. If financing options are available, they can increase the impact of state programs or fill financing gaps to ensure LI customers have access to PV. State governments may also be able to form partnerships with local developers, subgrantees, and financing partners to deliver LI PV programs cost-effectively. Specifically, states may want to consider options for accessing existing financial incentives, such as the federal ITC, by pursuing tax equity partners.

\section{Step 3: Develop Program Design}

If PV looks attractive for reducing LI energy burden and financing options are available, state policymakers may wish to consider program design options. Though policymakers will need to consider a wide variety of factors when developing LI PV programs, we focus on three here: evaluating necessary legislative or regulatory changes, the target population and its characteristics, and program impact. First, policymakers will need to consider which programs may be possible given existing statutory authority and whether additional legislative or regulatory action is necessary to enable certain partnerships or programmatic approaches.

\footnotetext{
${ }^{21}$ To support this type of analysis, NREL is developing a geospatial tool to provide solar potential analysis for suitable LI rooftops in the United States. For more information on this project, see "Project Profile: National Renewable Energy Laboratory (SEEDS2-SES),” DOE, https:/energy.gov/eere/solar/project-profile-nationalrenewable-energy-laboratory-seeds2-ses.

${ }^{22}$ For more information on PV Watts, see http://pvwatts.nrel.gov/, and for the System Advisor Model, see https://sam.nrel.gov/.
} 
Second, policymakers will need to determine which LI customer segments to target. In this effort, policymakers may benefit from an understanding of the implications associated with serving those customers based on their unique characteristics, such as housing type and income. These considerations can influence whether on-site or off-site PV projects will be available and which financing approaches may be most appropriate (Cook and Bird 2018). For example, WAP funding may be most applicable to on-site solar projects, but only for LI residents with income at or below $200 \%$ of the federal poverty level. ${ }^{23}$ Third, policymakers will need to determine the right balance between subsidizing individual bill savings and expanding overall LI participation. In the LI community solar program, CEO capped the subscription level per household to allow more participants while balancing the need for a meaningful bill credit. To support this decision, policymakers might conduct a portfolio analysis of potential low-income solar project options. A state could use quantitative analysis to weigh various program design options, such as which housing type to focus on, which funding sources (from Step 2) to leverage and pursue, the size of the pilots, potential solar business models, and other factors. This type of analysis can also characterize expected benefits for individual LI households and provide the necessary background for justifying new programs or investments.

\section{Step 4: Seek Approval}

In the process of designing a program, agency personnel will have to carry that program through the relevant approval processes. This may require state legislative approval, administrative approval, or in the case of LIHEAP and WAP, federal approval. For WAP, a variety of resources, including WAP Memo 024 (DOE 2017b) and the SIR tool (EERE 2016) may help other states reduce the time and resources needed to secure federal approval. For other programs, the relevant implementing agency will need to identify the proper approval channels. Regardless, state administrators or other stakeholders will likely need to educate decision makers of the benefits of LI PV programs in relation to achieving broader objectives. This will include demonstrating the rational for developing both on-site and off-site PV programs, as they may have different costs to the state. Finally, participating in a stakeholder process or public utility commission proceeding may represent a channel for establishing LI solar programs and incentives.

\section{Step 5: Implement and Learn from Pilots}

Initial program design might result in the launch of pilot projects that will allow states to learn from their efforts and then inform broader program design. To improve pilot success, states might identify willing and strong partners to carry out specific projects. These partners can be important in identifying potential LI customers, finding opportunities for reducing PV install costs, and navigating unforeseen challenges. Partners may also be able to offer key insight on performance to improve program operation in real time. In the case of CEO's LI community solar demonstration projects, the agency pursued cooperative and municipal utilities, given their flexibility to pursue novel LI community solar programs. Then, for CEO's WAP pilots, the agency partnered with longtime weatherization subgrantee, Energy Resource Center, and it was offered discounted PV at $\$ 2.35 / \mathrm{W}$ by local installer, El Paso Green Energy. As program implementation moves from pilots to broader deployment, states may wish to establish clear procurement guidelines. Such guidelines may be developed in consultation with stakeholders and

\footnotetext{
${ }^{23}$ For more information on WAP income eligibility requirements, see DOE (2017d).
} 
implementation partners to identify the most important criteria so that the program achieves its objectives (e.g., maximizing LI household benefits).

Step 6: Assess Impact and Next Steps

Once LI pilots or programs are fully implemented, a state might consider evaluating the program's performance in achieving their energy burden and deployment objectives. The state may wish to compare this performance with the cost of alternatives. From this basis, policymakers can then make modifications to improve performance while further reducing the energy burden of residents across the state. CEO engaged Lotus and NREL (Dobos et. al. 2017) to evaluate their LI community solar demonstration projects and this analysis provided the basis for subsequent PV program offerings. 


\section{Conclusion}

Overall, CEO's LI PV strategy was designed to maximize energy savings for LI customers by broadening access to both on-site and off-site PV. The strategy may result in the deployment of about 20 MW of LI-related PV through 2019. The implementation of the strategy offers several key lessons learned. First, the community solar demonstration projects revealed that LI solar projects could offer meaningful electricity bill savings for subscribers. Second, CEO's successful first-of-its-kind integration of PV into its weatherization program demonstrates how a state can leverage federal funding to support rooftop PV deployment for LI customers. Third, CEO's successful efforts to promote in-state utility investment in LI PV programs shows how such a partnership can significantly expand market impact. To be clear, in this report, we analyze only one of many strategies a state could employ to support LI PV deployment goals. However, as energy cost challenges persist, CEO's successful efforts in this space along with their lessons learned should serve as a helpful reference for states interested in leveraging PV to reduce residents' energy burden. 


\section{References}

ASPE (Office of the Assistant Secretary for Planning and Evaluation). n.d. U.S. Federal Poverty Guidelines Used to Determine Financial Eligibility for Certain Federal Programs.

https://aspe.hhs.gov/poverty-guidelines.

Baatz, Brendon. 2017. Rate Design Matters: The Intersection of Residential Rate Design and Energy Efficiency. http://aceee.org/sites/default/files/publications/researchreports/u1703.pdf.

Barbose, Galen, Naïm Darghouth, Ryan Wiser, Ben Hoen, and Dev Millstein. 2017. Income Trends among Residential Solar Adopters. Phase 1 Analysis for CESA SES Project. April 11, 2017.

Colorado Department of Human Services. 2017. Detailed Model Plan (LIHEAP). https://liheapch.acf.hhs.gov/sites/default/files/webfiles/docs/CO_Plan_2017.pdf.

CEO (Colorado Energy Office). 2015. Analysis of the Fulfillment of the Low-Income Carve-Out for Community Solar Subscriber Organizations.

https://www.colorado.gov/pacific/sites/default/files/atoms/files/CEO\%20Low-

Income $\% 20$ Community $\% 20$ Solar $\% 20$ Report.pdf.

- 2018. Colorado Energy Office.

https://www.colorado.gov/pacific/performancemanagement/colorado-energy-office.

CO PUC (Colorado Public Utilities Commission) 2016a. Interim Decision Granting Interventions and Amicus Curiae; Setting Hearing; and Adopting Procedural Schedule.

https://www.dora.state.co.us/pls/efi/efi_p2_v2_demo.show_document?p_dms_document_id=720 $\underline{583 .}$.

2016b. Decision Granting Motion to Approve Settlement, Granting Motion for Waivers, Denying Motion to Dismiss Application, Ordering Tariff Filings, Addressing New Proceeding on Trial and Pilot Rate Programs, Addressing Recovery of Renewable Compliance Plan Costs, and Addressing Future Resource Acquisitions.

https://www.dora.state.co.us/pls/efi/efi_p2_v2_demo.show_document?p_dms document id=720 $\underline{583}$.

Cook, Jeffrey J., and Lori Bird. 2018. Unlocking Solar for Low- and Moderate-Income Residents: A Matrix of Financing Options by Resident, Provider, and Housing Type. Golden, CO: National Renewable Energy Laboratory. NREL/TP-6A20-70477.

https://www.nrel.gov/docs/fy18osti/70477.pdf.

DOE (Department of Energy). 2012. Weatherization Energy Auditor Single Family Measure Selection Guidelines.

http://www.waptac.org/data/files/website_docs/training/standardized_curricula/energy_auditor_u pdated/17_measure_selection_guidelines_v2.0.pptx. 
. 2016. Weatherization Program Notice 16-7.

https://energy.gov/sites/prod/files/2016/06/f32/WPN\%2016-

7\%20Approved $\% 20$ Weatherization $\% 20$ Materials $\% 20$ with $\% 20$ Specifications $\% 20$ Revised.pdf.

2017a. Weatherization Program Notice 17-2.

http://www.waptac.org/data/files/website docs/government/guidance/2016/2017/wpn\%2017-

2\%20grantee $\% 20$ allocations $\% 20$ final.pdf.

- 2017b. WAP Memorandum 024.

https://energy.gov/sites/prod/files/2017/01/f34/WAPMEMO\%20024\%201.17.17.pdf.

- 2017c. U.S. Department of Energy Office of Energy Efficiency and Renewable Energy NEPA Determination. https://energy.gov/sites/prod/files/2017/03/f34/100823.pdf.

—. 2017d. Weatherization Program Notice 17-3 Effective Date: April 5, 2017. https://www.energy.gov/sites/prod/files/2017/04/f34/wpn-17-3.pdf.

HHS (U.S. Department of Health and Human Services. 2016. Weatherization: Coordinating LIHEAP and WAP.

https://iheapch.acf.hhs.gov/sites/default/files/webfiles/docs/LIHEAP_Weatherization_Report.pdf.

- 2017. 2017 Second Release of LIHEAP Block Grant Funds to States and Territories under the Consolidated Appropriations Act, 2017 (P.L. 115-31).

https://www.acf.hhs.gov/sites/default/files/ocs/dcl_final_release_statesterrs_table_calculations f y17.pdf.

Dobos, Hillary, Emily Artale, Douglas Gagne, Alexandra Aznar, Joseph Pereira, Gillian Weaver, and Lindsey Stegall. 2017. Insights from the Colorado Energy Office Low-Income Community Solar Demonstration Project.

https://www.colorado.gov/pacific/sites/default/files/Insights $\% 20$ from $\% 20$ the $\% 20 \mathrm{CEO} \% 20 \mathrm{Low}-$ Income\%20Community\%20Solar\%20Demonstration\%20Project.pdf.

Drehobl, Ariel, and Lauren Ross. 2016. Lifting the High Energy Burden in America's Largest Cities: How Energy Efficiency Can Improve Low Income and Underserved Communities. http://energyefficiencyforall.org/sites/default/files/Lifting\%20the\%20High\%20Energy\%20Burde $\underline{\text { n 0.pdf. }}$.

EERE (Office of Energy Efficiency and Renewable Energy, U.S. Department of Energy). 2016. New Analysis Shows National Potential for Solar Power in Low-Income Communities. https://energy.gov/eere/articles/new-analysis-shows-national-potential-solar-power-low-incomecommunities.

EIA (U.S. Energy Information Administration). 2009. Household Energy Use in Colorado. https://www.eia.gov/consumption/residential/reports/2009/state briefs/pdf/CO.pdf.

_.2017a. Colorado: State Profile and Energy Estimates.

https://www.eia.gov/state/seds/data.php?incfile=/state/seds/sep_prices/res/pr_res_CO.html\&sid= CO. 
/ 2017b.Colorado Electricity Profile 2015. Table 3. Top Five Retailers of Electricity, with End Use Sectors. https://www.eia.gov/electricity/state/colorado/xls/co.xlsx.

Feldman, David, Anna M. Brockway, Elaine Ulrich, and Robert Margolis. 2015. Shared Solar: Current Landscape, Market Potential, and the Impact of Federal Securities Regulation. Golden, CO: National Renewable Energy Laboratory. NREL/TP-6A20-63892. https://www.nrel.gov/docs/fy15osti/63892.pdf.

Figel, Tom. 2016. GRID Opening Testimony of Tom Figel.

https://www.dora.state.co.us/pls/efi/EFI.Show_Docket?p_session_id=\&p_docket id=16AL0048E.

Fu, Ran, David Feldman, Robert Margolis, Mike Woodhouse, and Kristen Ardani. 2017. U.S. Solar Photovoltaics System Cost Benchmark: Q1 2017. Golden, CO: National Renewable Energy Laboratory. NREL/TP-6A20-68925. https://www.nrel.gov/docs/fy17osti/68925.pdf.

GTM (GTM Research), and SEIA (Solar Energy Industries Association). 2016. U.S. Solar Market Insight Full Report 2016 Year in Review. https://www.seia.org/research-resources/solarmarket-insight-report-2016-year-review.

Hernandez, Mari. 2013. "Solar Power to the People: The Rise of Rooftop Solar Among Middle Class." Center for American Progress.

https://www.americanprogress.org/issues/green/reports/2013/10/21/76013/solar-power-to-thepeople-the-rise-of-rooftop-solar-among-the-middle-class/.

Higgins, Heatheryn, Patrice Lehermeier, and Howard Brooks. 2016. Colorado Launches First Low-Income Rooftop Solar Project within its Weatherization Assistance Program. Press release. https:/www.colorado.gov/pacific/sites/default/files/atoms/files/Colorado\%20Launches\%20First $\% 20$ Low-

Income \%20Rooftop $\% 20$ Solar\%20Project $\% 20$ within $\% 20$ its $\% 20$ Weatherization $\% 20$ Assistance $\%$ 20Program.pdf.

Paulos, Bentham. 2017. Bringing the Benefits of Solar Energy to Low-Income Consumers: A Guide for States and Municipalities. Clean Energy States Alliance. http://www.cesa.org/assets/2017-Files/Bringing-the-Benefits-of-Solar-to-Low-IncomeConsumers.pdf.

Pereira, Joseph. 2016a. Weatherization and Renewable Energy: The Colorado Experience. Presentation at NASCP. September 29, 2016.

- 2016b. Opening Settlement Testimony and Attachments of Joseph Pereira on Behalf of the Colorado Energy Office.

https://www.dora.state.co.us/pls/efi/EFI.Show_Docket?p_session_id=\&p_docket_id=16AL$\underline{0048 \mathrm{E}}$.

- 2016c. JP-2 Memorandum from Department of Energy Approving Rooftop Solar for Weatherization Assistance Program. 
https://www.dora.state.co.us/pls/efi/EFI.Show Docket?p session id=\&p docket id=16AL$\underline{0048 \mathrm{E}}$.

Ronen, Amit, Dor Hirsh Bar Gai, and Lucas Crampton. 2016. Can Electricity Rate Subsidies be Reallocated to Boost Low-Income Solar? George Washington Solar Institute.

https://solar.gwu.edu/can-electricity-rate-subsidies-be-reallocated-boost-low-income-solar.

SEPA (Smart Electric Power Alliance). 2017. $51^{\text {st }}$ State Perspectives Voices from Colorado's Global Energy Settlement. https://sepapower.org/resource/colorado-energy-settlement/.

Stewart, Z., M. Shah, J. Olsen, and G. Salas. 2017. Incorporating Solar PV Into Low Income Weatherization: Why and How. March 22 nd 2017 Presentation at 2017 HPC National Home Performance Conference and Trade Show.

U.S. Census Bureau. 2017. Quarterly Residential Vacancies and Homeownership: Second Quarter. https://www.census.gov/housing/hvs/files/currenthvspress.pdf.

Werley, Jensen. 2017. "Xcel Seeks Proposals for Solar Gardens to Benefit Low-Income Customers.” BizWest. https://bizwest.com/2017/08/24/xcel-seeks-proposals-solar-gardensbenefit-low-income-customers/.

Xcel Energy. 2016. Corrected Non-Unanimous Comprehensive Settlement Agreement. https://www.dora.state.co.us/pls/efi/EFI.Show_Docket?p_session_id=\&p_docket_id=16AL$\underline{0048 \mathrm{E}}$.

- 2018. 06S-016E December RESA Budget Report.

https://www.dora.state.co.us/pls/efi/EFI_Search_UI.search. 